\title{
Growth performance and blood profiles of striped catfish (Pangasianodon hypophthalmus) fed leaves extract of Myrmecodia tuberosa
}

\author{
RUDY AGUNG NUGROHO ${ }^{1, \bullet}$, ESTI HANDAYANI HARDI ${ }^{2}$, YANTI PUSPITA SARI ${ }^{3}$, RETNO ARYANI ${ }^{1}$, \\ RUDIANTO ${ }^{1}$ \\ ${ }^{1}$ Animal Physiology, Development, and Molecular Laboratory, Department of Biology, Faculty of Mathematics and Natural Sciences, Universitas \\ Mulawarman. J1. Barong Tongkok No. 4, Gunung Kelua, Samarinda 75123, East Kalimantan, Indonesia. Tel./fax.: +62-541-749140, 749152, 749153, \\ 749156, email: "email: rudyagung.nugroho@fmipa.unmul.ac.id \\ ${ }^{2}$ Department of Aquaculture, Faculty of Fisheries and Marine Science, Universitas Mulawarman. J1. Paser Balengkong, Gunung Kelua, Samarinda 75123, \\ East Kalimantan, Indonesia \\ ${ }^{3}$ Tissue Culture Laboratory, Department of Biology, Faculty of Mathematics and Natural Sciences, Universitas Mulawarman. Jl. Barong Tongkok No. 4, \\ Gunung Kelua, Samarinda 75123, East Kalimantan, Indonesia
}

Manuscript received: 15 February 2019. Revision accepted: 31 March 2019.

\begin{abstract}
Nugroho RA, Hardi EH, Sari YP, Aryani R, Rudianto. 2019. Growth performance and blood profiles of striped catfish (Pangasianodon hypophthalmus) fed leaves extract of Myrmecodia tuberosa. Nusantara Bioscience 11: 89-96. The application of plant extract in the aquaculture field is gaining momentum. This study aimed to determine the effects of $M$. tuberosa Jack leaves extract on the growth performance and blood profiles of striped catfish (Pangasianodon hypophthalmus). 400 fish with an initial average weight of $1.54 \pm 0.02 \mathrm{~g}$ were randomly divided into five groups and fed with different concentration of $M$. tuberosa Jack leaves extract $(0.25,0.5$, $1,2 \%$ ) and control diet for 80 days. Growth performance, feed conversion rate, feed efficiency, survival rate, morphometric, and hematological profile of the fish were evaluated at the end of the trial. The results found that fish fed $0.5-1 \%$ concentration had significantly higher $(P<0.05)$ growth, feed conversion rate, feed efficiency, morphometric value, survival, white blood cell, hemoglobin, neutrophil, lymphocyte, and monocyte than control. Meanwhile, supplementation of $2 \%$ MTE in the diet of fish reduced growth, feed utilization, viscerosomatic index, and morphometric values but increased red blood cell. All the supplemented diets decreased platelet of fish. The findings indicated that supplementation $0.5-1 \%$ of MTE is beneficial to the growth and blood profile of fish through the increment of growth indices, feed utilization, white blood cell, hemoglobin, neutrophil, lymphocyte, and survival rate of fish.
\end{abstract}

Keywords: Blood profiles, growth performance, leaf extract, Myrmecodia tuberosa, Pangasianodon hypophthalmus

\section{INTRODUCTION}

Stripped catfish (Pangasianodon hypothalamus) has increasingly become a pivotal commercial species in Africa, Europe and some part of Asia, especially Indonesia. It is also one of the most important fish species currently being cultured both within and outside its natural range of tropical and subtropical environments (Sousa et al. 2013; Yakubu et al. 2014; Da et al. 2016; Gopan et al. 2018). In addition, the striped catfish is relatively resistant to diseases, has high fecundity, and can easily be cultured, these make it an important part of the aquaculture industries in some countries (Haylor and Mollah 1995; Noor El-Deen et al. 2014; Ljubobratovic et al. 2015; Ranjan et al. 2018).

The application of bioactive compound from plant to increase growth and immunomodulatory in fish is becoming a common trend (Emre et al. 2013; Yildiz et al. 2013; Shitole et al. 2014; Rattaya et al. 2015; Soltanian and Fereidouni 2016). Compare to antibiotics and chemical compounds, several advantages of this method have been recognized to include its ability to (i) avoid risk of pathogen resistance; (ii) eco-friendly and without biomagnification; and (iii) minimum residue in the treated fish (Olusola et al. 2013; Reverter et al. 2014; Guardiola et al.
2016; Awad and Awaad 2017). One of the plants extract with such potential is Myrmecodia tuberosa Jack leaves extract (MTE).

Myrmecodia tuberosa Jack which is also known as antnest is an epiphytic plant with high antioxidant activity and medical value (Hertiani et al. 2010; Soeksmanto et al. 2010; Hanh et al. 2016). Generally, it is often used as a traditional medicine such as a health supplement for the mother's recovery after childbirth and during breastfeeding (Firdausy and Nurlaila 2016). A further report revealed that it enhances lymphocytes proliferation and macrophage phagocytosis activity and that it has antimicrobial properties against some pathogens such as Candida albicans, Escherichia coli, and Staphylococcus aureus (Efendi and Hertiani 2015). Moreover, Sumardi and Sasmito (2013) reported that its extract at $20 \mu \mathrm{g} \mathrm{mL}-1$ concentration showed the highest activity in immunity properties, especially in macrophage phagocytosis which is part of leukocyte.

Though some research regarding MTE in medical and pharmacy field has been conducted, the study of growth evaluation and immunomodulatory effects on stripped catfish has not been done. This is the first report of the effects of MTE Supplementation in the diet of fish. Therefore, this research was aimed at determining the 
growth and immunostimulant effect of the MTE in stripped catfish. To support this study, the phytochemical contents of MTE were qualitatively evaluated.

\section{MATERIALS AND METHODS}

\section{Plant material}

The Myrmecodia tuberosa leaves were collected from Antutan village and Mount White, District of Tanjung Palas, Bulungan, North Borneo, Indonesia, located at $02^{\circ} 15^{\prime} .43,8^{\prime \prime}-02^{\circ} 84^{\prime} .9,78^{\prime \prime}$ North Latitude and $117^{\circ} 29^{\prime} .60,9$ "- 117 $34^{\prime} .75,3^{\prime \prime}$ East Longitude. To eliminate extraneous matter, the leaves collected were washed with deionized water and immediately dried in an oven at $40^{\circ} \mathrm{C}$ for $12 \mathrm{~h}$. They were later cut and ground to make them powdery using a mill and the powder extracted using ethanol $95 \%$ for 3 days $\left(100 \mathrm{gL}^{-1}\right)$. After filtration, the $M$. tuberosa leaves extract (MTE) liquid was evaporated through the use of a rotary evaporator and stored at $4^{\circ} \mathrm{C}$ until it was used as a crude extract (Emulsion).

\section{Preliminary phytochemical tests}

Phytochemical Tests to detect the presence of possible phytochemicals in the extract such as alkaloid, saponin, steroid, triterpenoid, quinone, phenolic, tannin, and flavonoid were performed using methods as previously used by Nugroho et al. (2016), which were briefly described as follow:

(i) Alkaloid: This was conducted through the addition of $1 \mathrm{~mL}$ of Dragendorff reagent along the side of the test tube with $2 \mathrm{~mL}$ of the filtrate. Formation of orange or orange reddish-brown precipitate indicates a positive test.

(ii) Test for saponin: $1 \mathrm{~mL}$ of extract $+5 \mathrm{~mL}$ distilled water was shaken vigorously, the appearance of stable froth (1-3 height) for 15 minutes indicates the presence of saponin.

(iii) Test for steroids and (4) triterpenoid (LiebermannBurchard): $2 \mathrm{~mL}$ extract $+1 \mathrm{~mL}$ chloroform + few drops of acetic anhydride + conc. sulphuric acid was added along the side of the test tube. The appearance of a blue or green color indicates the presence of steroids while red or brown color indicates the presence of triterpenoid.

(v) Test for phenols and tannins: crude extract was mixed with $2 \mathrm{~mL}$ of $2 \%$ solution of $\mathrm{FeCl}_{3}$. A blue-green or black coloration indicates the presence of phenols and tannins.

(vi) Test for flavonoids: $2 \mathrm{~mL}$ extract + conc. hydrochloric acid + magnesium ribbon. The appearance of a pink-red color indicates the presence of flavonoids.

\section{Preparation of basal diet and test diet}

Basal diet pellet was bought from a commercial factory (Hi Pro Vite FF-888), containing 38-42\% protein, 4-6\% lipid, $2 \%$ crude fiber, $10 \%$ ash and $12 \%$ moisture while the test diet was prepared by mixing basal diet pellet with various concentration of MTE $(0.25 ; 0.50 ; 1 ;$ and $2 \%)$, repalletized using a mincer and dried with oven at $60^{\circ} \mathrm{C}$ for $24 \mathrm{~h}$. Dried pellets were then allowed to cool at room temperature, packed and stored in a dark room before use.

\section{Animals and experimental setup}

Four hundred stripped catfish with an initial average weight of $1.54 \pm 0.02 \mathrm{~g}$ were collected from the local fish hatchery in Samarinda, East Kalimantan and acclimated to the experimental conditions for one week. During this period, they were maintained on the basal diet. They were randomly distributed into 20 tanks $(125 \mathrm{~L}$ containing $100 \mathrm{~L}$ freshwater) at a density of 20 fish per tank and assigned to each of the 4 dietary various concentration of MTE and the control group. The tanks were equipped with electric motor pump (Grundfos type NSBasic 4-23) to ensure a constant flow of $0.54 \mathrm{~L} / \mathrm{min}$ for well-aerated water. For 80 days, the fish were fed with various concentrations of MTE tat the rate of $3 \%$ of their body weight three times per day.

A total of $30-50 \%$ of the water in the tanks was replaced with fresh water three times a week to adjust its quality. Temperature, $\mathrm{pH}$, total ammonia nitrate, nitrite, and dissolved oxygen of the water in experimental tanks were measured once a week using routine thermometer, $\mathrm{pH}$ meter (Eutech Instrument Cyberscan pH 11), Sera Kit test (Sera test kit ${ }^{\mathrm{TM}}$, SERA GMBH, Germany), and dissolved oxygen meter temperature probe (YSI 550A Clandon, Ohio, USA), respectively.

\section{Growth and feed utilization parameters}

At the end of 80 days feeding trial, biomass weight, average weekly gain (AWG), body weight gain (BWG), daily weight gain (DWG), specific growth rate (SGR), feed conversion ratio (FCR), feed efficiency (FE), and survival rate (SR), was measured to determine the growth and feed utilization of fish fed with various concentrations of MTE. All growth parameters were calculated by using equation previously used by Abdel-Tawwab et al. (2015); Githukia et al. (2015); Havas et al. (2015); Omosowone et al. (2015) as follow:

Body weight gain $(\mathrm{BWG})(\mathrm{g})=$ Final fish weight $(\mathrm{g})-$ Initial fish weight $(\mathrm{g})$

Average weekly gain $(\mathrm{AWG})(\mathrm{g})=$ Body weight gain $(\mathrm{g}) /$ number of weeks

$\operatorname{SGR}(\% /$ day $)=\left[\left(\mathrm{LnW}_{\mathrm{t}}-\mathrm{LnW}_{0}\right) /\left(\mathrm{T}_{2}-\mathrm{T}_{1}\right)\right] \times 100$

Where $\mathrm{W}_{0}$ is the initial fish weight $(\mathrm{g})$ at time $\mathrm{T}_{1}$ (day) and $\mathrm{W}_{\mathrm{t}}$ is the final fish weight $(\mathrm{g})$ at time $\mathrm{T}_{2}$ (day).

Feed efficiency $(\mathrm{FE})=[$ (Final fish weight $(\mathrm{g})+$ dead fish weight $(\mathrm{g}))$ - initial weight/Feed consumed ( $\mathrm{g}$ dry weight] $\mathrm{x} 100$

$\mathrm{FCR}=$ Feed consumed $(\mathrm{g}$ dry weight $) /$ Body weight gain.

\section{Viscera index}

Viscera and intestines of the fish were collected and weighed to calculate the Viscerosomatic index (VSI) and intestinosomatic index (ISI) at the end of the trial. They were calculated as follow:

$\operatorname{VSI}(\%)=100 \times($ viscera weight $[\mathrm{g}] /$ whole fish weight $[\mathrm{g}])$. ISI $(\%)=100 \mathrm{x}$ (intestinal weight $[\mathrm{g}] /$ whole fish weight $[\mathrm{g}])$. 


\section{Morphometric analysis}

After 80 days of the feeding trial, morphometric analysis of fish was measured as shown in Figure 1.

\section{TL}

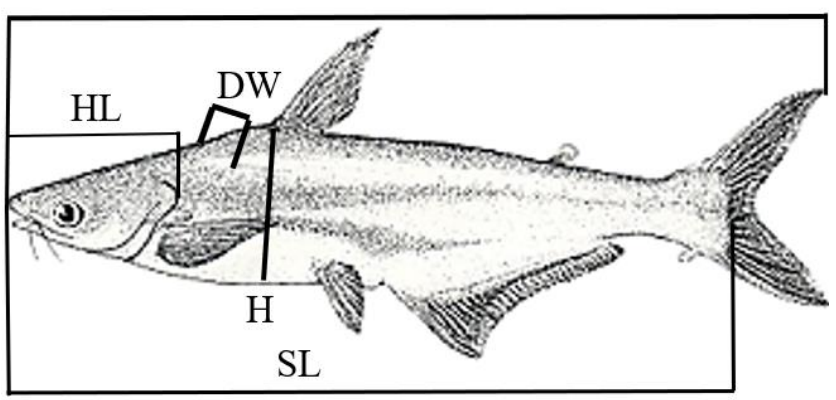

Figure 1. Morphometric measurement. TL $=$ Total length, $\mathrm{SL}=$ Standard length, $\mathrm{HL}=$ Head length, $\mathrm{DW}=$ Dorsal width, $\mathrm{H}=$ height

\section{Survival}

The survival rate of fish in each tank was recorded at days 0,40 , and 80 in accordance with the equation previously used by Okomoda et al. (2017).

Survival rate $(\mathrm{SR})(\%)=($ Final number of fish/initial number of fish) $\mathrm{x} 100$

\section{Hematological analysis}

At day 80, blood samples were collected from five fish in each tank using caudal venipuncture. Total RBC $\left(10^{6}\right.$ per $\left.\mathrm{mm}^{3}\right)$, WBC $\left(10^{3}\right.$ per $\left.\mathrm{mm}^{3}\right)$, Hemoglobin $(\mathrm{Hb})\left(\mathrm{g} \mathrm{dL}^{-1}\right)$, hematocrit (Htc), percentage of neutrophil, lymphocyte, and monocyte were determined by using Auto Hematology Analyzer (Mindray BC2800, Mindray® Shenzhen, China).

\section{RESULTS AND DISCUSSION}

The results showed that the average of temperature was $22.13 \pm 0.17^{\circ} \mathrm{C}, \mathrm{pH} 7.35 \pm 0.25$, DO $5.70 \pm 0.31 \mathrm{ppm}$, Nitrite $0.17 \pm 0.07 \mathrm{ppm}$, Ammonia $0.14 \pm 0.02 \mathrm{ppm}$, all of which were in the tolerable range for catfish culture (Freelancer, 2015). The findings from the qualitative phytochemicals screening revealed that the MTE positively contained Alkaloid, Triterpenoid, phenolic, tannin, and flavonoid (Table 1) and fish fed with $0.5-1 \%$ concentration had significantly higher final weight, BWG, AWG, SGR, FCR, and FE than other groups. However, the $2 \%$ concentration reduced all growth parameters (Table 2).

Significantly highest $(P<0.05)$ morphometric value for total length $(3.21 \pm 0.18 \mathrm{~cm})$, standard length $(2.89 \pm 0.11$ $\mathrm{cm})$, head length $(1.15 \pm 0.20 \mathrm{~cm})$, dorsal width $(1.14 \pm 0.21$ $\mathrm{cm})$, and height $(0.80 \pm 0.16 \mathrm{~cm})$ was achieved in the fish fed with $1 \%$ MTE (Table 3).

In visceral value, the addition of MTE higher than $1 \%$ also reduced VSI while the addition of $0.5 \%$ MTE resulted in significantly highest ISI $(6.48 \pm 0.57)$ (Table 4). The survival rate of fish fed with $2 \%$ MTE shown to be the lowest survival (85\%) compared to other groups (Figure 2). It was also discovered that the $0.5-1 \%$ concentration showed significantly better WBC, $\mathrm{Hb}$, neutrophil, lymphocyte, and monocyte. Nevertheless, supplementation higher than $1 \%$ increased $\mathrm{RBC}$ and $\mathrm{Htc}$ and all the concentrations decreased fish platelet (Table 5).

Table 1. Phytochemical screening test of ethanolic extract of Myrmecodia tuberosa leaves

\begin{tabular}{lc}
\hline \multicolumn{1}{c}{ Phytochemicals } & Results \\
\hline Alkaloid & + \\
Saponin & - \\
Steroid & - \\
Triterpenoid & + \\
Phenolic & + \\
Tannin & + \\
Flavonoid & + \\
\hline
\end{tabular}

(+) Present; (-) Absent

Table 2. Mean \pm SE growth and feed efficiency of Pangasianodon hypophthalmus fed dietary Myrmecodia tuberosa leaves extract (MTE) for 80 days

\begin{tabular}{lccccc}
\hline \multirow{2}{*}{ Parameters } & \multicolumn{5}{c}{ Groups MTE (\%) } \\
\cline { 2 - 6 } & Control & $\mathbf{0 . 2 5}$ & $\mathbf{0 . 5}$ & $\mathbf{1}$ & $\mathbf{2}$ \\
\hline Initial weight (g) & $1.565 \pm 0.005^{\mathrm{a}}$ & $1.541 \pm 0.005^{\mathrm{a}}$ & $1.531 \pm 0.016^{\mathrm{a}}$ & $1.527 \pm 0.013^{\mathrm{a}}$ & $1.538 \pm 0.008^{\mathrm{a}}$ \\
Final weight (g) & $3.531 \pm 0.006^{\mathrm{a}}$ & $3.527 \pm 0.036^{\mathrm{a}}$ & $3.739 \pm 0.049^{\mathrm{b}}$ & $3.808 \pm 0.042^{\mathrm{b}}$ & $3.356 \pm 0.147^{\mathrm{a}}$ \\
BWG (g) & $1.96 \pm 0.07^{\mathrm{a}}$ & $1.98 \pm 0.35^{\mathrm{a}}$ & $2.20 \pm 0.45^{\mathrm{b}}$ & $2.28 \pm 0.38^{\mathrm{b}}$ & $1.81 \pm 1.42^{\mathrm{a}}$ \\
AWG (g/week) & $1.72 \pm 0.006^{\mathrm{a}}$ & $1.74 \pm 0.030^{\mathrm{a}}$ & $1.93 \pm 0.039^{\mathrm{b}}$ & $2.00 \pm 0.033^{\mathrm{b}}$ & $1.59 \pm 0.125^{\mathrm{c}}$ \\
SGR (\%/day) & $1.017 \pm 0.004^{\mathrm{a}}$ & $1.034 \pm 0.012^{\mathrm{a}}$ & $1.115 \pm 0.016^{\mathrm{b}}$ & $1.142 \pm 0.013^{\mathrm{b}}$ & $0.971 \pm 0.049^{\mathrm{c}}$ \\
FCR & $1.27 \pm 0.008^{\mathrm{a}}$ & $1.24 \pm 0.022^{\mathrm{a}}$ & $1.11 \pm 0.024^{\mathrm{b}}$ & $1.07 \pm 0.019^{\mathrm{b}}$ & $1.33 \pm 0.074^{\mathrm{a}}$ \\
FE (\%) & $78.50 \pm .019^{\mathrm{a}}$ & $80.48 \pm 0.19^{\mathrm{a}}$ & $90.13 \pm 0.07^{\mathrm{b}}$ & $93.39 \pm 0.33^{\mathrm{b}}$ & $75.91 \pm 0.33^{\mathrm{a}}$ \\
\hline
\end{tabular}

Note: Different alphabets $(\mathrm{a}, \mathrm{b}, \mathrm{c})$ indicated significantly different means for different treatments at $P<0.05$. Control group $=$ without Myrmecodia tuberosa leaves extract supplementation. BWG = Body weight gain, DWG = Daily weight gain, AWG = Average weekly gain, $\mathrm{SGR}=$ Specific growth rate, $\mathrm{FCR}=$ Feed conversion ratio. 
Table 3. Morphometric value of Pangasianodon hypophthalmus fed dietary Myrmecodia tuberosa leaves extract for 80 days

\begin{tabular}{lccccc}
\hline \multirow{2}{*}{ Parameters } & \multicolumn{5}{c}{ Groups MTE (\%) } \\
\cline { 2 - 6 } & Control & $\mathbf{0 . 2 5}$ & $\mathbf{0 . 5}$ & $\mathbf{1}$ & \multicolumn{2}{c}{} \\
\hline Total length (cm) & $2.68 \pm 0.08^{\mathrm{a}}$ & $2.48 \pm 0.14^{\mathrm{a}}$ & $2.55 \pm 1.11^{\mathrm{a}}$ & $3.21 \pm 0.18^{\mathrm{b}}$ & $2.46 \pm 0.09^{\mathrm{a}}$ \\
Standard length (cm) & $2.50 \pm 0.21^{\mathrm{a}}$ & $2.15 \pm 0.06^{\mathrm{a}}$ & $2.09 \pm 0.10^{\mathrm{ab}}$ & $2.89 \pm 0.11^{\mathrm{c}}$ & $1.99 \pm 0.08^{\mathrm{b}}$ \\
Head length (cm) & $0.53 \pm 0.01^{\mathrm{a}}$ & $0.54 \pm 0.02^{\mathrm{a}}$ & $0.53 \pm 0.02^{\mathrm{a}}$ & $1.15 \pm 0.20^{\mathrm{b}}$ & $0.53 \pm 0.01^{\mathrm{a}}$ \\
Dorsal width (cm) & $0.40 \pm 0.07^{\mathrm{a}}$ & $0.48 \pm 0.02^{\mathrm{a}}$ & $0.44 \pm 0.02^{\mathrm{a}}$ & $1.14 \pm 0.21^{\mathrm{b}}$ & $0.49 \pm 0.03^{\mathrm{a}}$ \\
Height (cm) & $0.40 \pm 0.07^{\mathrm{a}}$ & $0.19 \pm 0.008^{\mathrm{a}}$ & $0.19 \pm 0.01^{\mathrm{a}}$ & $0.80 \pm 0.16^{\mathrm{b}}$ & $0.23 \pm 0.01^{\mathrm{a}}$ \\
\hline
\end{tabular}

Note: Different alphabets $(\mathrm{a}, \mathrm{b}, \mathrm{c})$ indicate significantly different means for different treatments at $\mathrm{P}<0.05$. Control group $=$ without Myrmecodia tuberosa leaves extract.

Table 4. Viscerosomatic and intestinal somatic index of Pangasianodon hypophthalmus fed dietary Myrmecodia tuberosa leaves extract (MTE) in the diet for 80 days

\begin{tabular}{lccccc}
\hline & \multirow{2}{*}{ Parameters } & \multicolumn{5}{c}{ Groups MTE (\%) } \\
\cline { 2 - 6 } & Control & $\mathbf{0 . 2 5}$ & $\mathbf{0 . 5}$ & $\mathbf{1}$ & \multicolumn{2}{c}{} \\
\hline VSI & $12.79 \pm 0.42^{\mathrm{a}}$ & $15.86 \pm 0.42^{\mathrm{b}}$ & $14.80 \pm 0.72^{\mathrm{bc}}$ & $14.06 \pm 0.24^{\mathrm{c}}$ & $9.09 \pm 0.26^{\mathrm{d}}$ \\
ISI & $1.26 \pm 0.11^{\mathrm{a}}$ & $5.37 \pm 0.51^{\mathrm{b}}$ & $6.48 \pm 0.57 \mathrm{~b}^{\mathrm{c}}$ & $4.87 \pm 0.41^{\mathrm{b}}$ & $4.38 \pm 0.18^{\mathrm{b}}$ \\
\hline
\end{tabular}

Note: Different alphabets $(\mathrm{a}, \mathrm{b}, \mathrm{c})$ indicated significantly different means for different treatments at $\mathrm{P}<0.05$. Control group $=$ without Myrmecodia tuberosa leaves extract supplementation. VSI = Viscerosomatic Index, ISI = Intestinal somatic index.

Table 5. Hematological profiles of Pangasianodon hypophthalmus fed Myrmecodia tuberosa leaves extract for 80 days

\begin{tabular}{lccccc}
\hline \multicolumn{1}{c}{ Parameters } & \multicolumn{5}{c}{ Group (\%) } \\
\cline { 2 - 6 } & Control & $\mathbf{0 . 2 5}$ & $\mathbf{0 . 5}$ & $\mathbf{1}$ & $\mathbf{2}$ \\
\hline RBC $\left(10^{6} \mu \mathrm{L}^{-1}\right)$ & $0.91 \pm 0.01^{\mathrm{a}}$ & $0.91 \pm 0.01^{\mathrm{a}}$ & $0.91 \pm 0.01^{\mathrm{a}}$ & $0.92 \pm 0.01^{\mathrm{a}}$ & $0.97 \pm 0.01^{\mathrm{b}}$ \\
WBC $\left(10^{3} \mu \mathrm{L}^{-1}\right)$ & $6.82 \pm 0.24^{\mathrm{a}}$ & $7.01 \pm 0.10^{\mathrm{a}}$ & $10.77 \pm 0.10^{\mathrm{b}}$ & $11.01 \pm 0.13^{\mathrm{b}}$ & $8.79 \pm 0.28^{\mathrm{c}}$ \\
Hemoglobin $\left(\mathrm{g} \mathrm{dL} \mathrm{L}^{-1}\right)$ & $5.50 \pm 0.19^{\mathrm{a}}$ & $5.50 \pm 0.10^{\mathrm{a}}$ & $6.10 \pm 0.25^{\mathrm{b}}$ & $6.50 \pm 0.10^{\mathrm{b}}$ & $6.50 \pm 0.11^{\mathrm{b}}$ \\
PLT $\left(10^{3} \mu \mathrm{L}^{-1}\right)$ & $309.00 \pm 16.84^{\mathrm{a}}$ & $173.00 \pm 4.12^{\mathrm{b}}$ & $207.00 \pm 11.12^{\mathrm{c}}$ & $183.00 \pm 4.12^{\mathrm{bc}}$ & $202.00 \pm 9.30^{\mathrm{bc}}$ \\
Neutrophil $\left(10^{3} \mu \mathrm{L}^{-1}\right)$ & $4.77 \pm 0.11^{\mathrm{a}}$ & $5.10 \pm 0.04^{\mathrm{b}}$ & $8.30 \pm 0.06^{\mathrm{c}}$ & $9.01 \pm 0.12^{\mathrm{d}}$ & $7.07 \pm 0.02^{\mathrm{c}}$ \\
Lymphocyte $\left(10^{3} \mu \mathrm{L}^{-1}\right)$ & $0.88 \pm 0.01^{\mathrm{a}}$ & $0.55 \pm 0.04^{\mathrm{b}}$ & $1.25 \pm 0.03^{\mathrm{c}}$ & $1.42 \pm 0.03^{\mathrm{d}}$ & $1.19 \pm 0.03^{\mathrm{c}}$ \\
Monocyte $\left(10^{3} \mu \mathrm{L}^{-1}\right)$ & $0.48 \pm 0.01^{\mathrm{a}}$ & $0.52 \pm 0.03^{\mathrm{a}}$ & $0.65 \pm 0.01^{\mathrm{b}}$ & $0.50 \pm 0.02^{\mathrm{a}}$ & $0.51 \pm 0.06^{\mathrm{b}}$ \\
\hline
\end{tabular}

Note: Different alphabets (a, b, c, d) indicated significantly different means for different treatments at $P<0.05$. Control group $=$ without Myrmecodia tuberosa leaves extract supplementation. $\mathrm{RBC}=\mathrm{Red}$ blood cell, $\mathrm{WBC}=$ White blood cell, $\mathrm{PLT}=\mathrm{Platelet}$

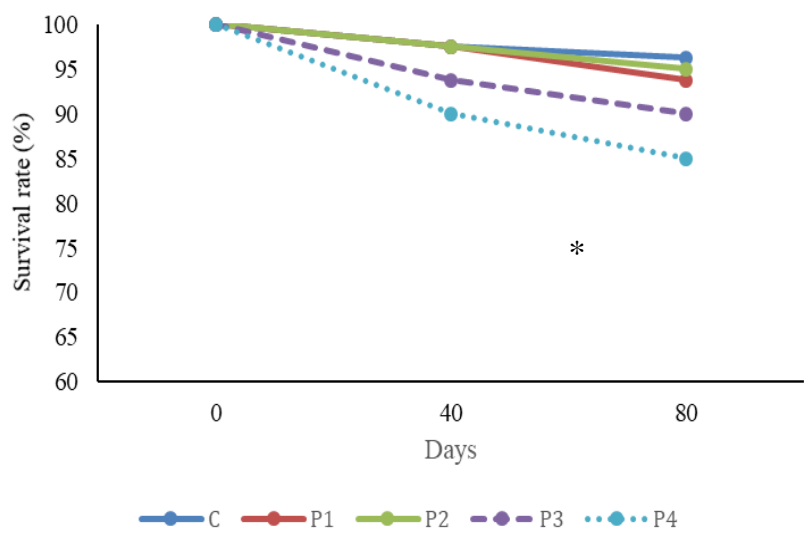

Figure 2. Survival rate (\%) of stripped catfish (Pangasianodon hypophthalmus) fed Myrmecodia tuberosa leaves extract in the diet for 80 days. Note: $\mathrm{P} 1=0.25 \%, \mathrm{P} 2=0.5 \%, \mathrm{P} 3=1 \%, \mathrm{P} 4=2 \%$

\section{Discussion}

The use of plant extracts in aquaculture to promote growth and immunity has been gaining momentum (Soofiani et al. 2016; Abdel-Tawwab, Adeshina, et al. 2018; Adeshina et al. 2018; Rahman et al. 2018; Tan et al. 2018). Plant extracts have several important biologically active compounds such as a flavonoid, alkaloid, triterpenoid, phenolic and tannin (Nugroho et al. 2016; George et al. 2017; Barrett et al. 2018) which was also contained in MTE (Sari et al. 2017 as well as proven in this present study (Table 1).

The MTE supplementation in the diet of $P$. hypothalamus affected the fish growth status and morphometric value. This might be due to the presence of phytochemical compounds such as flavonoid which is an important secondary metabolite that can act as primary antioxidants because of its antibacterial properties (Rattanachaikunsopon and Phumkhachorn 2007) and as a 
growth booster on juvenile Pargus major (JI et al. 2007), Carassius auratus (Ahilan et al. 2010), Catla catla (Kaleeswaran et al. 2011). In fish, free radicals which are naturally produced during metabolism can be scavenged by non-enzymatic antioxidants. The increasing level of free radical that cannot be scavenged by antioxidant may affect the growth of fish. In line with this study, (Izzreen and Fadzelly, 2013) who found flavonoid-containing Green Tea, Camellia sinensis, stated that flavonoid can be used to improve the growth of Nile Tilapia, Oreochromis niloticus (Abdel-Tawwab et al. 2010). Apart from this compound, other plant secondary metabolites like triterpenoid, quinone, and phenolic have also been reported to enhance various physiological status like ant stress, growth, appetite, tonic, and immunity (Citarasu 2010; Suman Bhusan Chakraborty et al. 2012; Suman B Chakraborty et al. 2014).

The immunity of fish is related to its blood profile (Satheeshkumar et al. 2012; Soberon et al. 2014; Simide et al. 2016; Moazenzadeh et al. 2017) which are valuable in monitoring and assessing fish health (Abbass et al. 2012; Karimi et al. 2013; Kızak et al. 2013; Wang et al. 2014; He et al. 2015; Suely et al. 2016). Blood profiles such as RBC, WBC, Hb, Htc, and PLT are major variables to evaluate the physiological status of a fish. Current research found that groups of fish fed with diet mixed with MTE showed significantly higher RBC, WBC and $\mathrm{Hb}$ which are used as an indicator of blood profile in fish and related to innate immune protection and regulation of immunological function in the organisms (Ballarin et al. 2004). Further, the WBC value is generally used as an indicator of fish's health status because it is pivotal to their innate immune defense and functioning (Shiau et al. 2015; Franz et al. 2016). Present research revealed that WBC and $\mathrm{Hb}$ of fish fed with $0.5-1 \%$ MTE showed significantly higher improvement than other groups. This is similar to past study, stating that plant extracts containing active phytochemicals may boost the value WBC and $\mathrm{Hb}$ in fish (Barreca et al. 2009; Dotta et al. 2014; Yuniar et al. 2017). In addition, the ethanolic extract of $M$. tuberosa containing phenolic compound helps in improving the immune system (Firdausy and Nurlaila 2016).

However, the mechanism pertaining to increment of blood profiles in fish fed diet supplemented with MTE is not clearly understood. Nair et al. (2002), Lyu and Park (2005) revealed that flavonoid from plant extract may modulate Th-1 derived cytokines such as IL-2 (Interleukin 2) and INF $\gamma$ (Interferon). They may act as biocatalysts in producing WBC as part of nonspecific cellular immunity. Furthermore, they help in reducing hemolysis of RBC and protecting their biological membranes from oxidative damage caused by free radicals (Kitagawa et al. 1992; Asgary et al. 2005). Therefore, this research seems to be in line with past research that MTE containing flavonoids is capable of being an antioxidant which can be used to maintain the heme iron and enhance erythropoiesis (Akah et al. 2008; Uboh et al. 2010; Shatoor 2011).

Furthermore, secondary metabolites from the plant may improve the innate immune system of fish in order to support their survival (Suman Bhusan Chakraborty et al.
2012). Previous research revealed that phytochemicals from plant extract have been successfully used to promote the survival rate of Common Carp (Cyprinus carpio) (Mohamad and Abasali 2010); marine ornamental fish (Balachandran and Tissera 2013) and tilapia (Oreochromis niloticus) (Akinwande et al. 2011). In addition, Dhanalaxmi and Vastrad (2014) found that cinnamon (Cinnamomum verum) which contained active phytochemicals is useful in increasing the survival rate of Nile tilapia after challenged with Aeromonas hydrophila (Abdel-Tawwab, Samir, et al. 2018). Current study, however, indicated that $P$. hypothalamus fed with MTE above $1 \%$ significantly reduced $(P<0.05)$ survival rate. The highest value of survival rate (Figure 3 ) was found in $0.5 \%$ concentration which does not significantly difference with control group. This might be because of the presence of tannin in the MTE which could be harmful to fish at high concentration. Previously, Viswaranjan et al. (1988) reported that tannin which is dominantly present in plants, has negative effects on Channa striatus and Cyprinus carpio such as decreasing the lipid content on the liver, brain, muscle and protein depletion suffered in their brain. Further, this negative impact may correlate with the increase of mortality.

In conclusions, the Myrmecodia tuberosa leaves extract contains phytochemicals such as flavonoid, tannin, alkaloid which support growth and blood profile of $P$. hypothalamus. A diet supplement with $1 \%$ of MTE is recommended to enhance growth and immune function of the fish. However, further research needs to be conducted to examine the influence of those plants on fish health (including histological parameters and molecular aspect) as an important step for its large-scale application in aquaculture.

\section{ACKNOWLEDGEMENTS}

The authors thanking Kementerian Riset dan Teknologi Pendidikan Tinggi (Ministry of Research and Technology General Higher Education) for the grant, contract number 074/UN.17.41/KL/2018 Through Penelitian Dasar Unggulan Perguruan Tinggi (PDUPT) 2018. All authors also thank to Faculty of Mathematics and Natural Sciences, Mulawarman University, East Kalimantan, Samarinda for any kinds of support.

\section{REFERENCES}

Abbass AA, El-Asely AM, Kandiel MM. 2012. Effects of dietary propolis and pollen on growth performance, fecundity and some hematological parameters of Oreochromis niloticus. Turk J Fish Aquat Sci 12 (4): 851-859. DOI: 10.4194/1303-2712-v12_4_13

Abdel-Tawwab M, Adeshina I, Jenyo-Oni A, Ajani EK, Emikpe BO. 2018. Growth, physiological, antioxidants, and immune response of African Catfish, Clarias gariepinus (B.), to dietary clove basil, Ocimum gratissimum, leaf extract and its susceptibility to Listeria monocytogenes infection. Fish Shellfish Immunol 78: 346-354. DOI: 10.1016/j.fsi.2018.04.057

Abdel-Tawwab M, Ahmad MH, Seden MEA, Sakr SFM. 2010. Use of green tea, Camellia sinensis L in practical diet for growth and protection of Nile tilapia, Oreochromis niloticus (L.), against 
Aeromonas hydrophila infection. J World Aquac Soc 41 (s2): 203213. DOI: $10.1111 / \mathrm{j} .1749-7345.2010 .00360$.x

Abdel-Tawwab M, Hagras AE, Elbaghdady HAM, Monier MN. 2015. Effects of dissolved oxygen and fish size on Nile Tilapia, Oreochromis niloticus (L.): Growth performance, whole-body composition, and innate immunity. Aquac Intl 23 (5): 1261-1274. DOI: $10.1007 / \mathrm{s} 10499-015-9882-\mathrm{y}$

Abdel-Tawwab M, Samir F, Abd El-Naby AS, Monier MN. 2018. Antioxidative and immunostimulatory effect of dietary cinnamon nanoparticles on the performance of Nile Tilapia, Oreochromis niloticus (L.) and its susceptibility to hypoxia stress and Aeromonas hydrophila infection. Fish Shellfish Immunol 74: 19-25. DOI: 10.1016/j.fsi.2017.12.033

Adeshina I, Jenyo-Oni A, Emikpe BO, Ajani EK, Abdel-Tawwab M. 2018. Stimulatory Effect of dietary clove, Eugenia caryophyllata, Bud extract on growth performance, nutrient utilization, antioxidant capacity, and tolerance of African Catfish, Clarias gariepinus (B.), to Aeromonas hydrophila infection. J World Aquac Soc. DOI: $10.1111 /$ jwas. 12565

Ahilan B, Nithiyapriyatharshini A, Ravaneshwaran K. 2010. Influence of Certain Herbal Additives on the Growth, Survival and Disease Resistance of Goldfish, Carassius auratus (Linnaeus). Tamilnadu J Vet Anim Sci 6 (1): 5-11.

Akah P, Okpi O, Okoli C. 2008. Evaluation of the anti-inflammatory, analgesic and antimicrobial activities of bark of Afzelia africana. Nigerian J Nat Prod Med 11 (1): 48-52. DOI 10.4314/njnpm.v11i1.11881

Akinwande A, Dada A, Moody F. 2011. Effect of dietary administration of the phytochemical "Genistein" (3, 5, 7, 3, 4 Pentahydroxyflavone) on masculine tilapia, Oreochromis niloticus. Elixir Aqua 33: 22312233.

Asgary S, Naderi GH, Askari NMS. 2005. Protective effect of flavonoids against red blood cell hemolysis by free radicals. Exp Clin Cardiol 10 (2): $88-90$

Awad E, Awaad A. 2017. Role of medicinal plants on growth performance and immune status in fish. Fish Shellfish Immunol. DOI: 10.1016/j.fsi.2017.05.034

Balachandran N, Tissera K. 2013. A study on the effect of using mangrove leaf extracts as a feed additive in the progress of bacterial infections in marine ornamental fish. J Coast Life Med 1 (3): 217 224.

Ballarin L, Dall'Oro M, Bertotto D, Libertini A, Francescon A, Barbaro A. 2004. Haematological parameters in Umbrina cirrosa (Teleostei, Sciaenidae): A comparison between diploid and triploid specimens. Comp Biochem Physiol A Mol Integr Physiol 138 (1): 45-51. DOI: 10.1016/j.cbpb.2004.02.019

Barreca D, Laganà G, Tellone E, Ficarra S, Leuzzi U, Galtieri A, Bellocco E. 2009. Influences of flavonoids on erythrocyte membrane and metabolic implication through anionic exchange modulation. J Membr Biol 230 (3): 163-171. DOI: 10.1007/s00232-009-9197-x

Barrett AH, Farhadi NF, Smith TJ. 2018. Slowing starch digestion and inhibiting digestive enzyme activity using plant flavanols/tannins-a review of efficacy and mechanisms. LWT - Food Sci Technol 87: 394-399. DOI: $10.1016 /$ j.lwt.2017.09.002

Chakraborty SB, Horn P, Hancz C. 2014. Application of phytochemicals as growth-promoters and endocrine modulators in fish culture. Rev Aquac 6 (1): 1-19. DOI: $10.1111 /$ raq.12021

Chakraborty SB, Molnár T, Hancz C. 2012. Effects of methyltestosterone, tamoxifen, genistein and Basella alba extract on masculinization of guppy (Poecilia reticulata). J Appl Pharm Sci 2 (12): 48. DOI: 10.7324/JAPS.2012.21209

Citarasu T. 2010. Herbal biomedicines: a new opportunity for aquaculture industry. Aquac Int, 18 (3): 403-414. DOI: 10.1007/s10499-0099253-7

Da CT, Lundh T, Lindberg JE, Berg H. 2016. Growth performance, feed utilisation and biological indices of Tra Catfish (Pangasianodon hypophthalmus) cultured in net cages in pond fed diets based on locally available feed resources. Intl Aquat Res 8 (4): 309-321. DOI: 10.1007/s40071-016-0144-z

Dhanalaxmi R, Vastrad J. 2014. Phytoconstituents: an analysis of cinnamon (Cinnamomum verum) leaf extracts. AJHS, 9 (1): 319-321.

Dotta G, de Andrade JIA, Gonçalves ELT, Brum A, Mattos JJ, Maraschin M, Martins ML. 2014. Leukocyte phagocytosis and lysozyme activity in Nile tilapia fed supplemented diet with natural extracts of propolis and Aloe barbadensis. Fish Shellfish Immunol 39 (2): 280-284. DOI 10.1016/j.fsi.2014.05.020
Efendi YN, Hertiani T. 2015. Antimicrobial potency of ant-plant extract (Myrmecodia tuberosa Jack.) against Candida albicans, Escherichia coli, and Staphylococcus aureus. Trad Med J 18 (1): 46-52. DOI: 10.22146/tradmedj.7944

Emre Y, Ergün S, Kurtoğlu A, Güroy B, Güroy D. 2013. Effects of ulva meal on growth performance of gilthead seabream (Sparus aurata) at different levels of dietary lipid. Turk J Fish Aquat Sci 13: 841-846. DOI: 10.4194/1303-2712-v13_5_08

Firdausy AF, Nurlaila ES. 2016. Acute toxicity of non-hexane fraction of ethanolic extract of ant-plant (Myrmecodia tuberose (Jack) B1.) hypocotyls in rats. IJPCR 8 (1): 6-9.

Franz A-C, Faass O, Köllner B, Shved N, Link K, Casanova A, Wenger M, D'Cotta H, Baroiller J-F, Ullrich O. 2016. Endocrine and local Igf-I in the bony fish immune system. Biology 5 (1): 9. DOI: 10.3390/biology5010009

Freelancer. 2015. Pangasius Farming: Water Quality and Biosecurity. https://thefishsite.com/articles/pangasius-farming-water-quality-andbiosecurity. [16 March 2019]

George VC, Dellaire G, Rupasinghe HV. 2017. Plant flavonoids in cancer chemoprevention: role in genome stability. J Nutr Biochem 45: 1-14. DOI: 10.1016/j.jnutbio.2016.11.007

Githukia CM, Ogello EO, Kembenya EM, Achieng AO, Obiero KO, Munguti JM. 2015. Comparative growth performance of male monosex and mixed sex Nile Tilapia (Oreochromis niloticus L.) reared in earthen ponds. CJF Ribarstvo 73 (1): 20-25. DOI: 10.14798/73.1.788

Gopan A, Ande MP, Varghese T, Sahu NP, Lalappan S, Srivastava P, Jain K. 2018. Dietary carotenoid supplementation improves fillet appearance, antioxidant status and immuneresponses in striped catfish (Pangasianodon hypophthalmus) nevertheless the growth performance. Turk J Fish Aquat Sci 18 (11): 1303-1313. DOI: 10.4194/1303-2712-v18_11_07

Guardiola F, Porcino C, Cerezuela R, Cuesta A, Faggio C, Esteban M. 2016. Impact of date palm fruits extracts and probiotic enriched diet on antioxidant status, innate immune response and immune-related gene expression of European Seabass (Dicentrarchus labrax). Fish Shellfish Immunol 52: 298-308. DOI: 10.1016/j.fsi.2016.03.152

Hanh NP, Phan NHT, Thuan NTD, Hanh TTH, Vien LT, Thao NP, Thanh NV, Cuong NX, Binh NQ, Nam NH. 2016. Two new simple iridoids from the ant-plant Myrmecodia tuberosa and Their Antimicrobial Effects. Nat. Prod. Res 30 (18): 2071-2076. DOI: 10.1080/14786419.2015.1113412

Havas M, Kumar S, Nagy Z, Beliczky G, Nagy S, Bercsény M, Gál D. 2015. Effects of feeding regime on growth feed conversion and size variation of Silurus glanis. CJF Ribarstvo 73 (4): 142-147. DOI: 10.14798/73.4.846

Haylor GS, Mollah MFA. 1995. Controlled hatchery production of African Catfish, Clarias gariepinus: The influence of temperature on early development Aquat Living Resour 8: $8 . \quad$ DOI: 10.1051/alr:1995051

He J, Qiang J, Gabriel NN, Xu P, Yang R. 2015. Effect of feedingintensity stress on biochemical and hematological indices of gift tilapia (Oreochromis niloticus). Turk. J. Fish. Aquat. Sci 15 (2): 303310. DOI: 10.4194/1303-2712-v15_2_12

Hertiani T, Sasmito E, Sumardi, Ulfah M. 2010. Preliminary study on immunomodulatory effect of sarang-semut tubers Myrmecodia tuberosa and Myrmecodia pendens. OJBS 10 (3): 136-141. DOI: 10.3844/ojbsci.2010.136.141

Izzreen NMQ, Fadzelly MA. 2013. Phytochemicals and antioxidant properties of different parts of Camellia sinensis Leaves from Sabah Tea Plantation in Sabah, Malaysia. IFRJ 20 (1): 307.

JI SC, Takaoka O, Jeong GS, Lee SW, Ishimaru K, Seoka M, Takii K. 2007. Dietary medicinal herbs improve growth and some non-specific immunity of red sea bream Pagrus major. Fish Sci 73 (1): 63-69. DOI: $10.1111 / \mathrm{j} .1444-2906.2007 .01302 . \mathrm{x}$

Kaleeswaran B, Ilavenil S, Ravikumar S. 2011. Growth response, feed conversion ratio and antiprotease activity of Cynodon dactylon (L.) mixed diet in Catla catla (Ham.). JAVA 10 (4): 511-517. DOI: 10.3923/javaa.2011.511.517

Karimi S, Kochinian P, Salati A. 2013. The effect of sexuality on some haematological parameters of the yellowfin seabream, Acanthopagrus latus in Persian Gulf. IJVR 14 (1): 65-68. DOI: 10.22099/ijvr.2013.1392

Kitagawa S, Fujisawa H, Sakurai H. 1992. Scavenging effects of dihydric and polyhydric phenols on superoxide anion radicals, studied by 
electron spin resonance spectrometry. Chem Pharm Bull 40 (2): 304307. DOI: $10.1248 / \mathrm{cpb} .40 .304$

Kızak V, Güner Y, Türel M, Kayım M. 2013. Comparison of growth performance, gonadal structure and erythrocyte size in triploid and diploid brown trout (Salmo trutta Fario L, 1758). Turk J Fish Aquat Sci 13 (4). DOI: 10.4194/1303-2712-v13_4_02

Ljubobratovic U, Kucska B, Feledi T, Poleksic V, Markovic Z, Lenhardt M, Peteri A, Kumar S, Ronyai A. 2015. Effect of weaning strategies on growth and survival of pikeperch, Sander lucioperca, Larvae. Turk J Fish Aquat Sci 15: 7. DOI: 10.4194/1303-2712-v15_2_15

Lyu S-Y, Park W-B. 2005. Production of cytokine and no by raw 264.7 macrophages and PBMC in vitro incubation with flavonoids. Arch Pharm Res 28 (5): 573. DOI: 10.1007/BF02977761

Moazenzadeh K, Islami HR, Zamini A, Soltani M. 2017. Dietary zinc requirement of siberian sturgeon (Acipenser baerii, Brandt 1869) juveniles, based on the growth performance and blood parameters. Intl Aquat Res 9 (1): 25-35. DOI: 10.1007/s40071-017-0153-6

Mohamad S, Abasali H. 2010. Effect of plant extracts supplemented diets on immunity and resistance to Aeromonas hydrophila in common carp (Cyprinus carpio). Agric J 5 (2): 119-127. DOI: 10.3923/aj.2010.119.127

Nair MP, Kandaswami C, Mahajan S, Chadha KC, Chawda R, Nair H, Kumar N, Nair RE, Schwartz SA. 2002. The flavonoid, quercetin, differentially regulates Th-1 (Ifn $\gamma$ ) and Th-2 (Il4) cytokine gene expression by normal peripheral blood mononuclear cells. Biophys Acta Mol Cell Res 1593 (1): 29-36. DOI: 10.1016/S0167-4889 (02)00328-2

Noor El-Deen AI, Mona SZ, Shalby SI. 2014. Increasing catfish production as a try to combat growth crayfish in the River Nile and its branches Life Sci 11 (9): 3 .

Nugroho RA, Manurung H, Saraswati D, Ladyescha D, Nur FM. 2016. The effects of Terminalia catappa L. leaves extract on the water quality properties, survival and blood profile of ornamental fish (Betta Sp) cultured. Biosaintifika: Journal of Biology and Biology Education 8 (2): 240-247.

Okomoda VT, Tiamiyu LO, Wase G. 2017. Effects of tank background colour on growth performance and feed utilization of African catfish Clarias gariepinus (Burchell, 1822) fingerlings. CJF Ribarstvo 75 (1): 5-11. DOI: $10.1515 / \mathrm{cjf}-2017-0002$

Olusola SE, Emikpe BO, Olaifa FE. 2013. The potentials of medicinal plant extract as bio-antimicrobials in aquaculture. Int. J. Med. Aromat. Plants 3: 404-412.

Omosowone O, Dada A, Adeparusi E. 2015. Effects of dietary supplementation of fumaric acid on growth performance of African catfish Clarias gariepinus and Aeromonas sobria challenge. CJF Ribarstvo 73 (1): 13-19. DOI: 10.14798/73.1.782

Rahman ANA, Khalil AA, Abdallah H, ElHady M. 2018. The effects of the dietary supplementation of Echinacea purpurea extract and/or vitamin $\mathrm{c}$ on the intestinal histomorphology, phagocytic activity, and gene expression of the Nile Tilapia. Fish Shellfish Immunol 82: 312318. DOI: $10.1016 /$ j.fsi.2018.08.024

Ranjan A, Jain KK, Srivastava PP, Muralidhar PA. 2018. Dietary energy requirement of Pangasianodon hypophthalmus (Sauvage, 1878) juveniles reared at two temperatures. Turk J Fish Aquat Sci 18 (1): 101-108. DOI: 10.4194/1303-2712-v18_1_11

Rattanachaikunsopon P, Phumkhachorn P. 2007. Bacteriostatic effect of flavonoids isolated from leaves of Psidium guajava on fish pathogens. Fitoterapia 78 (6): 434-436. DOI: 10.1016/j.fitote.2007.03.015

Rattaya S, Benjakul S, Prodpran T. 2015. Extraction, antioxidative, and antimicrobial activities of brown seaweed extracts, Turbinaria ornata and Sargassum polycystum, grown in Thailand. Intl Aquat Res 7 (1): 1-16. DOI: $10.1007 / \mathrm{s} 40071-014-0085-3$

Reverter M, Bontemps N, Lecchini D, Banaigs B, Sasal P. 2014. Use of plant extracts in fish aquaculture as an alternative to chemotherapy: current status and future perspectives. Aquaculture 433: 50-61. DOI: 10.1016/j.aquaculture.2014.05.048

Sari YP, Kustiawan W, Sukartiningsih S, Ruchaemi A. 2017. The potential of secondary metabolites of Myrmecodia tuberosa from different host trees. Nusantara Biosci 9 (2): 170-174. DOI: 10.13057/nusbiosci/n090211

Satheeshkumar P, Ananthan G, Kumar DS, Jagadeesan L. 2012 Haematology and biochemical parameters of different feeding behaviour of teleost fishes from Vellar Estuary, India. Comp Clin Path 21 (6): 1187-1191. DOI: 10.1007/s00580-011-1259-7
Shatoor AS. 2011. Acute and sub-acute toxicity of Crataegus aronia Syn. Azarolus (L.) whole plant aqueous extract in Wistar Rats. Am J Pharmacol Toxicol 6 (2): 37-45. DOI: 10.3844/ajptsp.2011.37.45

Shiau S-Y, Gabaudan J, Lin Y-H. 2015. Dietary nucleotide supplementation enhances immune responses and survival to Streptococcus iniae in hybrid tilapia fed diet containing low fish $\begin{array}{llll}\text { meal. Aquacult Rep 2: 77-81. DOI: } & \end{array}$ https//DOI.org/10.1016/j.aqrep.2015.08.002

Shitole SS, Balange AK, Gangan SS. 2014. Use of seaweed (Sargassum tenerrimum) extract as gel enhancer for lesser sardine (Sardinella brachiosoma) surimi. Intl Aquat Res 6 (1): 55 . DOI: 10.1007/s40071-014-0055-9

Simide R, Richard S, Prévot-D'Alvise N, Miard T, Gaillard S. 2016. Assessment of the accuracy of physiological blood indicators for the evaluation of stress, health status and welfare in Siberian sturgeon (Acipenser baerii) subject to chronic heat stress and dietary supplementation. Intl Aquat Res 8 (2): 121-135. DOI: 10.1007/s40071-016-0128-z

Soberon L, Mathews P, Malherios A. 2014. Hematological parameters of Colossoma macropomum naturally parasitized by Anacanthorus spathulatus (Monogenea: Dactylogiridae) in fish farm in the Peruvian Amazon. Intl Aquat Res 6 (4): 251-255. DOI: 10.1007/s40071-0140087-1

Soeksmanto A, Subroto M, Wijaya H, Simanjuntak P. 2010. Anticancer activity test for extracts of sarang semut plant (Myrmecodya pendens) to Hela and Mcm-B2 Cells. Pakistan J Biol Sci 13 (3): 148-151.

Soltanian S, Fereidouni MS. 2016. Effect of henna (Lawsonia inermis) extract on the immunity and survival of common carp, Cyprinus carpio Infected with Aeromonas hydrophila. Intl Aquat Res 8 (3): 247-261. DOI: 10.1007/s40071-016-0141-2

Soofiani NM, Babahydari SB, Dorafshan S, Vahabi M, Heyrati FP. 2016. The physiological changes, growth performance and whole body composition of common carp, Cyprinus carpio fed on diet containing wood betony, Stachys lavandulifolia extract. JAST 16: 1565-1574.

Sousa SMN, Freccia A, Santos LD, Meurer F, Tessaro L, Bombardelli RA. 2013. Growth of Nile tilapia post-larvae from broodstock fed diet with different levels of digestible protein and digestible energy. Rev. Bras. Zootec 42 (8): 535-540. DOI: 10.1590/S151635982013000800001

Suely A, Zabed H, Ahmed A, Mohamad J, Nasiruddin M, Sahu J, Ganesan P. 2016. Toxicological and hematological effect of Terminalia arjuna bark extract on a freshwater catfish, Heteropneustes fossilis. Fish Physiol Biochem 42 (2): 431-444. DOI: 10.1007/s10695-015-0149-3

Sumardi TH, Sasmito E. 2013. Ant plant (Myrmecodia tuberosa) hypocotyl extract modulates Tcd4+ and Tcd8+ cell profile of doxorubicin-induced immune-suppressed Sprague Dawley Rats in Vivo. Sci Pharm 81 (4): 1057. DOI: 10.3797/scipharm.1302-03

Tan X, Sun Z, Liu Q, Ye H, Zou C, Ye C, Wang A, Lin H. 2018. Effects of dietary Ginkgo biloba leaf extract on growth performance, plasma biochemical parameters, fish composition, immune responses, liver histology, and immune and apoptosis-related genes expression of hybrid grouper (Epinephelus lanceolatus $\widehat{ } \times$ Epinephelus fuscoguttatus ) ) fed high lipid diets. Fish Shellfish Immunol 72: 399409. DOI: $10.1016 /$ j.fsi.2017.10.022

Uboh FE, Okon IE, Ekong MB. 2010. Effect of aqueous extract of Psidium guajava leaves on liver enzymes, histological integrity and hematological indices in rats. Gastroenterol Res 3 (1): 32. DOI: $10.4021 / \mathrm{gr} 2010.02 .174 \mathrm{w}$

Viswaranjan S, Beena S, Palavesam A. 1988. Effect of tannic acid on the protein, carbohydrate and lipid levels in the tissues of the fish Oreochromis mossambicus. Environ Ecol 6 (2): 289-292.

Wang A, Han G, Lv F, Yang W, Huang J, Yin X. 2014. Effects of dietary lipid levels on growth performance, apparent digestibility coefficients of nutrients, and blood characteristics of juvenile crucian carp (Carassius auratus Gibelio). Turk J Fish Aquat Sci 14 (1): 1-10. DOI: 10.4194/1303-2712-v14_1_01

Yakubu AF, Nwogu NA, Olaji ED, Ajiboye OO, Apochi JO, Adams TE, Obule EE, Eke M. 2014. A comparative study on growth performance and survival rate of Clarias gariepinus Burchell, 1822 and Heterobranchus longifilis Valenciennes, 1840 underwater recirculation system. Agric For Fisher 3 (1): 30-33. DOI: 10.11648/j.aff.20140301.16

Yıldız M, Eroldoğan OT, Engin K, Gülçubuk A, Baltacı MA. 2013. Effects of dietary cottonseed and/or canola oil inclusion on the growth performance, fa composition and organ histology of the juvenile 
rainbow trout, Oncorhynchus mykiss. Turk J Fish Aquat Sci 13 (3). DOI: 10.4194/1303-2712-v13_3_08

Yuniar I, Darmanto W, Soegianto A. 2017. Effect of saponin-pods extract acacia (Acacia mangium) to hematocrit, hemoglobin at tilapia
(Oreochromis niloticus). UNEJ e-Proceeding, 67-69. DOI: 10.19184/psni.v2016i1.4138. 